\title{
A late Campanian Euselachian Assemblage from the Bearpaw Formation of Alberta, Canada: Some Notable Range Extensions
}

\begin{tabular}{|c|c|}
\hline Journal: & Canadian Journal of Earth Sciences \\
\hline Manuscript ID & cjes-2016-0233.R1 \\
\hline Manuscript Type: & Article \\
\hline Date Submitted by the Author: & 02-May-2017 \\
\hline Complete List of Authors: & $\begin{array}{l}\text { Cook, Todd D.; Penn State Erie the Behrend College School of Science } \\
\text { Brown, Eric; Penn State Erie the Behrend College School of Science } \\
\text { Ralrick, Patricia; Royal Tyrrell Museum } \\
\text { Konishi, Takuya; University of Cincinnati }\end{array}$ \\
\hline $\begin{array}{r}\text { Is the invited manuscript for } \\
\text { consideration in a Special } \\
\text { Issue? : }\end{array}$ & N/A \\
\hline Keyword: & Euselachian, Campanian, Western Interior Seaway, Palaeobiogeography \\
\hline
\end{tabular}




\section{A late Campanian Euselachian Assemblage from the Bearpaw}

\section{Formation of Alberta, Canada: Some Notable Range}

\section{Extensions}

\section{Todd D. Cook, Eric Brown, Patricia E. Ralrick, and Takuya Konishi}

Todd D. Cook. ${ }^{1}$ School of Science, Penn State Behrend, 4205 College Drive, Erie, PA 16563, USA, tdc15@psu.edu

Eric Brown. School of Science, Penn State Behrend, 4205 College Drive, Erie, PA 16563,USA, ebrownrma@gmail.com

Patricia E. Ralrick. Royal Tyrrell Museum of Palaeontology, Drumheller, AB T0J 0Y0, Canada, patty.ralrick@gov.ab.ca

Takuya Konishi. Department of Biological Sciences, University of Cincinnati, Cincinnati, OH 45221, USA, konishta@ucmail.uc.edu

${ }^{1}$ Corresponding author. 


\title{
A late Campanian Euselachian Assemblage from the Bearpaw
}

\section{Formation of Alberta, Canada: Some Notable Range}

\section{Extensions}

\author{
Todd D. Cook, Eric Brown, Patricia E. Ralrick, and Takuya Konishi
}

\begin{abstract}
Herein, we report an euselachian assemblage from the late Campanian Bearpaw Formation recovered from southern Alberta, Canada. This small yet uniquely diverse fauna includes the northern-most occurrences of Paraorthacodus andersoni, Squalus worlandensis, Odontaspis aculeatus, and Archaeotriakis ornatus within the Western Interior Seaway. It also constitutes the first record of $P$. andersoni, S. worlandensis, and A. ornatus from Canadian deposits. Moreover, we report the stratigraphically youngest record of Cretoxyrhina mantelli. This assemblage is unique in that all the identifiable euselachian species are either pelagic or benthopelagic but not benthic. This is in stark contrast to the batoid-rich euselachian assemblage of the Lethbridge Coal Zone that immediately underlies the Bearpaw Formation in southern Alberta. We attribute this difference to dysoxic bottom waters during the deposition of the formation, rather than to sampling bias.
\end{abstract}




\section{Introduction}

Late Cretaceous (100-66 Ma) North America was divided in two land masses by the Western Interior Seaway (WIS), a large intercontinental sea that extended from the Arctic Ocean to the Gulf of Mexico (e.g., Kauffman 1984). The Bearpaw Formation was deposited in the late Campanian to early Maastrichtian during the last major transgression event of this seaway (Caldwell 1968; Kauffman 1984; Caldwell et al. 1993). This formation outcrops in the Canadian provinces of Alberta and Saskatchewan and has produced well-preserved marine reptile remains including elasmosaurid and polycotylid plesiosaurs (e.g., Sato 2003, 2005; Kubo et al. 2012) and three subfamilies of mosasaurs (e.g., Tokaryk 1993; Holmes 1996; Holmes et al. 1999; Bullard 2006; Konishi 2012; Konishi et al. 2011, 2014). However, very little is known about euselachian diversity from the Bearpaw Formation in this relatively high-palaeolatitudinal region of the WIS (Beavan and Russell 1999). Previously, Mahaney et al. (2013) reported probable shark coprolites from the Bearpaw Formation of Saskatchewan and Konishi et al. (2014), in their description of the marine reptile Mosasaurus missouriensis from the same formation of Alberta, noted the likely scavenging of the carcass by lamniform selachians.

Recently, an upper Campanian euselachian assemblage was collected from five microsites from the Bearpaw Formation exposed in the vicinity of Dorothy, southern Alberta, Canada. The fossil remains, consisting largely of isolated teeth, represent one of the most northern euselachian faunas within the Campanian Western Interior Basin. The purpose of this research is to identify the euselachian taxa and assist in habitat reconstruction of this portion of the seaway. Additionally, a faunal comparison with contemporaneous euselachian assemblages from well-documented sites in lower 
palaeolatitudinal regions within the seaway provides insights into palaeobiogeographical patterns of the identified taxa.

\section{Geology}

During the deposition of the Bearpaw Formation, southern Alberta would have been situated within an embayment along the western margin of the WIS and west of a submarine topographic high known as the Sweetgrass Arch (Tsujita and Westermann 1998). The formation overlies the non-marine to marginal-marine Dinosaur Park Formation and underlies the marginal-marine Blood Reserve, Horseshoe Canyon and Eastend formations (Tsujita and Westermann 1998, and references therein) and consists of marine sands and silty clays intercalated with bentonite layers (Mahaney et al. 2013, and references therein; pers. observ.) (Fig. 1).

\section{Materials and methods}

All the fossil material was recovered within the $1.25 \mathrm{~km}$ linear distance along the south side of the Red Deer River in Dorothy, Alberta, Canada (51¹6' 29"N, $112^{\circ} 19^{\prime} 43^{\prime \prime} \mathrm{W}$ to $\left.51^{\circ} 15^{\prime} 57^{\prime \prime} \mathrm{N}, 112^{\circ} 19^{\prime} 5^{\prime \prime} \mathrm{W}\right)$. Most of the specimens were collected in situ from five microvertebrate sites concentrated within a 150 m diameter (DSnail, MSnail-13, and Tsnail; specific UTM coordinates available in the Royal Tyrrell Museum of Palaeontology collections database). Fossils from those microsites were first collected through dry, bulk sampling of the matrix on site, approximately $100 \mathrm{~kg}$ in total mass, which was then screen washed with micro-sieving (No. 20/0.841 $\mathrm{mm}$ mesh) at the museum. TMP 2011.048.274 and TMP 2011.048.291 were surface collected 
approximately 560m and 1240m SE from MSnail-1 respectively, MSnail-1 constituting the northernmost collection site. All the specimens including the surface-collected material were recovered from just below the top of the Dorothy Bentonite dated at 73.2 Ma, and are middle late Campanian in age (Konishi 2012, and references therein). All the specimens are curated at the Royal Tyrrell Museum of Palaeontology, Drumheller, Alberta. An S-570 Hitachi Scanning Electron Microscope was used to image the specimens. Dental terminology and euselachian taxonomy largely follows that of Cappetta (2012).

\section{Systematic Palaeontology}

Class Chondrichthyes Huxley, 1880

Subclass Elasmobranchii Bonaparte, 1838

Cohort Euselachii Hay, 1902

Order Hybodontiformes Maisey, 1975

Family Hybodontidae Owen, 1846

Genus Meristodonoides Underwood and Cumbaa, 2010

Meristodonoides montanensis (Case, 1978)

Fig. 2A and B

Referred material: TMP 2011.048.0232, incomplete tooth (MSnail-1 microsite); TMP 2011.048.0325, incomplete tooth (MSnail-1 microsite).

Description: Teeth with an erect median cusp with very strong convex labial and lingual crown faces. Distinct striations are restricted to the lower one-third on both faces. TMP 2011.048.0232A preserves a single incomplete lateral cusplet. A well-developed cutting 
edge runs continuous from the apex to the base of the crown. The root is highly fractured in both specimens.

Remarks: Case (1978) originally described Hybodus montanensis from the late Campanian Judith River Formation of Montana and was subsequently reported from the late Campanian Teapot Member of the Mesaverde Formation of Wyoming (Case 1987) and the Lethbridge Coal Zone of the Dinosaur Park Formation of Alberta (Beavan and Russell 1999). Differences in overall tooth morphology with Hybodus s.s. Agassiz, 1837 led Underwood and Cumbaa (2010) to reassign several species previously reported as Hybodus, including H. montanensis, to Meristodonoides. To date, this species has only been reported from the WIS.

Order Hexanchiformes Buen, 1926

Family Paraorthacodontidae Glikman, 1958

Genus Paraorthacodus Glikman, 1957

Paraorthacodus andersoni (Case, 1978)

Fig. 2C

Referred material: TMP 2011.048.0097 (DSnail microsite), incomplete lateral tooth. Description: Tooth with a median cusp that is slightly distally inclined. The labial crown face is very slightly convex, whereas the lingual face is strongly convex. Both faces bear well-developed striations that are restricted to the lower half of the cusp. Only a single distal lateral cusplet is preserved and also bears distinct striations. The cutting edge runs continuously the median cusp and lateral cusplet. The labial root face is more or less flat and is not overhung by the labial crown face. Multiple nutrient grooves are present along 
the basal edge and are restricted to the labial region of the basal face. The lingual root face is expanded labiolingually and bears two distinct grooves containing two large foramina just below the crown-root boundary. In addition, smaller foramina are scattered throughout this root face.

Remarks: This is only the second report of Paraorthocodus andersoni from the WIS and the first documented occurrence from Canada. Case (1978) originally described this species from the Judith River Formation of Montana. Teeth from a second Paraorthocodus species described as P. striatus by Case (1978) from the same formation were revealed to be posterior teeth of $P$. andersoni by Siverson (1992a). As such, only a single Paraorthocodus species is currently known to have inhabited the waters of the WIS.

Order Squaliformes Goodrich, 1909

Family Squalidae Bonaparte, 1834

Genus Squalus Linnaeus, 1758

Squalus worlandensis (Case, 1987)

Fig. 2D-G

Referred material: TMP 2011.048.0196, nearly complete lateral tooth (TSnail microsite); TMP 2011.048.0323, complete lateral tooth (TSnail microsite); TMP 2011.048.0269, incomplete lateral tooth (MSnail-1); TMP 2011.048.0324, incomplete lateral tooth (MSnail-1).

Description: Lateral teeth are labiolingually compressed and possess a broad median cusp that is strongly distally inclined. Both labial and lingual crown faces are smooth. The 
mesial cutting edge is convex or sigmoid in contour, whereas the distal edge is strictly convex. A well-developed convex distal heel is separated from the median cusp by a notch. The elongated labial apron extends below the lobate basal edge of the root. The lingual crown face bears a distinct uvula that is continuous with the lingual bulge of the root. A large central foramen and multiple labial and lingual marginal foramina are present.

Remarks: Case (1987) originally described Centrophoroides worlandensis from the late Campanian Teapot Member of the Mesaverde Formation of Wyoming. This species was subsequently reassigned to Squalus by Case and Cappetta (1997). The teeth reported herein are the only second documented occurrence in WIS, as well as the first record of this genus from Cretaceous deposits of Canada, and greatly extends the palaeobiogeographical range of this species.

The presence of Squalus is relatively rare within the WIS. The species $S$. huntensis, reported from the Maastrichtian Kemp Formation of Texas (Case and Cappetta 1997), can be distinguished from $S$. wolandensis by the considerably smaller median cusp. The Palaeocene species S. minor, from the Cannonball Formation of North Dakota (Cvancara and Hoganson 1993), has a less distinct notch between the median cusp and the distal heel. This latter species has a relatively large palaeobiogeographical range also being reported along the East Coast of North America (Ward and Weist 1990; Case 1996) and Europe and northern Africa (Daimeries 1888; Gurr 1962; Casier 1967; Herman 1973).

Order Lamniformes Berg, 1958 
Family Odontaspididae Müller and Henle, 1839

Genus Carcharias Rafinesque, 1810

Carcharias cf. C. samhammeri (Cappetta and Case, 1975)

Fig. 3A-D

Referred material: TMP 2011.048.0291, incomplete lower anterior tooth (surface collected); TMP 2011.048.0156, incomplete upper anterior tooth (MSnail-3 microsite); TMP 2011.048.0187, incomplete upper lateral tooth (TSnail microsite); TMP 2011.048.0228, incomplete posterior tooth (MSnail-1 microsite).

Description: Anterior teeth have a median cusp that is very slightly distally inclined. The labial crown face is slightly convex and overhangs the labial root face. The lingual crown face is strongly convex. Both crown faces are smooth. TMP 2011.048.0291 has a distinct cutting edge that runs continuously from the apex to a pair of small lateral cusplets. The lateral cusplets of TMP 2011.048.0156 have been fractured and are missing. The lingual neck is present. The lingual protuberance is well-developed and has a prominent nutrient groove that houses a single central foramen. The distal root lobe is elongated and somewhat labiolingually compressed, whereas the mesial root lobe is missing. The basal concavity is deep.

Lateral tooth exhibits a large distally inclined median cusp. The smooth labial crown face is slightly convex, whereas the smooth lingual face is strongly convex. A marked notch separates the median cusp from the single preserved distal lateral cusplet. A distinct cutting edge runs continuously across the crown. The lingual neck is welldeveloped. The lingual protuberance has a prominent nutrient groove. The distal root lobe 
is slightly labiolingually compressed and has a rounded edge. The mesial root lobe is missing. The basal concavity is shallower than that of the anterior tooth.

A tooth that would have been situated in the posterior region of the jaw has a median cusp that is considerably reduced in size and a labial root face that is greater in height than that of the labial crown face.

Remarks: Compagno and Follet $(1986$, p. 89, 90) noted that the anterior teeth of extant Carcharias have "stout and broad-tipped" median cusps that are flanked by "short and strongly hooked" lateral cusplets, whereas the lateral teeth are "compressed and bladelike" and the teeth situated near the jaw commissure are "strongly differentiated as carinate, molariform crushers". The Carcharias dentition described herein largely follows this general morphology.

Cappetta and Case (1975) originally described Carcharias samhammeri (as Odontaspis samhammeri) from the early Maastrichtian Mount Laurel Formation of New Jersey. Kent (1994) and Hartstein et al. (1999) also reported C. sammhammeri from the late Maastrichtian Severn Formation of the Chesapeake Bay region. Potential reports of this species from the WIS include the late Maastrichtian Fox Hills Formation of South Dakota (Becker et al. 2004, as Carcharias cf. C. samhammeri) and Kemp Formation of Texas (Case and Cappetta 1997, as Carcharis cf. samhammeri).

Previous reports of Carcharias from the Campanian of Alberta include C. steineri (Case, 1987) from the underlying Lethbridge Coal Zone of the Dinosaur Park Formation (Beavan and Russell, 1999). This species, originally described by Case (1987) as Odontaspis steineri from the late Campanian Mesaverde Formation of Wyoming, has well-developed enameloid folding along the basal region of the labial crown face. The 
relatively smooth crowns of the teeth figured by Beavan and Russell (1999, fig 3.9-3.12) from the Dinosaur Park Formation appears to be more akin to that of C. samhammeri than to that of $C$. steineri.

\author{
Genus Odontaspis Agassiz, 1838 \\ Odontaspis aculeatus (Cappetta and Case, 1975)
}

Fig. 3E-H

Referred material: TMP 2011.048.0215, incomplete anterior tooth (MSnail-1 microsite); TMP 2011.048.0221, incomplete lower lateral tooth (MSnail-1 microsite); TMP 2011.048.0217, incomplete upper lateral tooth (MSnail-1 microsite); TMP 2011.048.0222, incomplete upper lateral tooth (MSnail-1 microsite).

Description: Anterior tooth has a slender and erect median cusp. The slightly convex labial face has a basal edge that overhangs the labial root face. The lingual face is strongly convex. Both crown faces are smooth. The cutting edge does not reach the base of the median cusp. Flanking the median cusp are two pairs of lateral cusplets; however only the mesial cusplets are preserved. The apex of proximal cusplet is missing. The distal cusplet is considerably smaller and is curved towards the median cusp. A distinct lingual neck is present. The lingual protuberance has a well-developed nutrient groove. A series of relatively large foramina are located below the labial basal edge of the crown, whereas numerous smaller foramina are found throughout the lingual root face. The majority of the root lobes are missing.

Lateral teeth have a median cusp that becomes increasingly more distally inclined moving towards the jaw commissure and is considerably reduced in the posterior-most 
files. The labial crown is slightly convex, whereas the lingual face is strongly convex. The median cusp may be flanked by up to three pairs of lateral cusplets. The most proximal pair of cusplets is relatively robust and extends one-third the height of the median cusp. The basal region of the labial crown face bears short enameloid folding. The cutting edge is interrupted between the median cusp and lateral cusplets. A distinct lingual neck is present. The lingual protuberance has a well-developed nutrient groove. The labial root face bears a series of large foramina below the labial basal edge, whereas the lingual face has numerous smaller foramina. The basal concavity separates the root lobes.

Remarks: Compagno and Follet (1986, p. 90) noted that the anterior teeth of extant Odontaspis have "slender and narrow-tipped" median cusps and lateral cusplets that are "long and straight or weakly curved", whereas the lateral dentition are not compressed and the teeth situated near the jaw commissure are "not differentiated as molariform crushers". This describes the overall morphology of the Odontaspis dentition reported herein.

Odontaspis aculeatus was originally described by Cappetta and Case (1975, as Hypotodus aculeatus) from late Campanian Mount Laurel Formation of New Jersey. Within WIS deposits, this species has been reported from the Maastrichtian Kemp Formation of Texas (Case and Cappetta 1997), Arkadelphia Formation of Arkansas (Becker et al. 2006), and Fox Hills Formation of South Dakota (Becker et al. 2004). Case (1978, p. 190) erected Odontaspis grandis (as Hypotodus grandis) from the late Campanian Judith River Formation of Montana and distinguished this species from $O$. aculeatus based on a larger size and differences in "lateral cusp shape" of the former. In 
their report of latter species from the Dinosaur Park Formation, Beavan and Russell $(1999$, p. 499) noted that their examination of the O. grandis topotype material did not warrant new species designation; however, they went on to compare the species Carcharias sanguieni and $O$. grandis and noted that differences in tooth morphology "clearly separates them as two distinct taxa". We have not examined the O. grandis type material, thus we conservatively assign these teeth to $O$. aculeatus at this time.

Family Cretoxyrhinidae Glikman, 1958

Genus Cretoxyrhina Glikman, 1958

Cretoxyrhina mantelli (Agassiz, 1843)

Fig. 3I

Referred material: TMP 2011.048.0274, nearly complete lateral tooth (surface collected). Description: Lateral tooth with a single large labiolingually compressed median cusp that is distally inclined. The apex of the cusp is missing. The labial crown face is more or less flat, whereas the lingual face is convex. Both crown faces are smooth. A mesial cutting edge is weakly sigmoid, whereas the distal edge is concave. There is a very weak distal notch between the cusp and a low and oblique distal heel. A lingual neck is present. The lingual protuberance lacks a nutrient groove. The mesial root lobe is slightly elongated and separated from its distal lobe by a shallow basal concavity.

Remarks: Comparing the overall size of TMP 2011.048.0274 with that of multiple Cretoxyrhina mantelli teeth described and figured by Siverson and Lindgren (2005, fig.2), it is apparent that the Bearpaw specimen represents a lateral tooth of a juvenile. Siverson and Lindgren (2005) also noted the latest occurrence of species from the WIS 
was early Campanian; whereas the last report of this species from northern Europe was slightly younger. Siverson (1992b) described a single tooth from the lower-most upper Campanian of Sweden but cautiously stated the possibility of reworking due to its poor preservation. Although the root of TMP 2011.048.0274 does indicate some erosion, the crown shows very little signs of wear. Consequently, the Bearpaw specimen may represent the youngest documented occurrence of $C$. mantelli. However, since only a single tooth was recovered, we cautiously suggest a stratigraphic extension for this species.

\author{
Order Carcharhiniformes Compagno, 1973 \\ Family Triakidae Gray, 1851 \\ Genus Archaeotriakis Case, 1978 \\ Archaeotriakis ornatus (Case, 1987)
}

Fig. 3J

Referred material: TMP 2011.048.0237, incomplete tooth (MSnail-1 microsite).

Description: Small tooth with a broad triangular median cusp that is flanked by welldeveloped and divergent lateral cusplets. One lateral cusplet bears an incipient cusplet at the base. The labial crown face slightly overhangs the labial root face near the crown-root boundary. The labial face of the median cusp bears three distinct enameloid folds found on the central region of the cusp. The lingual face of the median cusp has numerous folds that are restricted to the base. The holaulacorhizous root has an expanded base face and has a central and margino-lingual foramen. 
Remarks: This is second documented report of Archaeotriakis ornatus to date and extends its palaeobiogeographical range to the north. Case (1987) originally described this species from the Teapot Member of the Mesaverde Formation of Wyoming. Along with this species, Case (1987) also reported the congeneric $A$. rochelleae which was first reported from the Judith River Formation of Montana (Case 1978) and can be largely differentiated from $A$. ornatus by its smooth lingual crown face and labial crown face that does not overhang the root.

\section{Discussion}

This relatively small pelagic or benthopelagic Bearpaw assemblage includes seven species from five orders, six families, and seven genera and represents a slight temporal extension for Cretoxyrhina mantelli and a northerly palaeobiogeographical extension for Meristodonoides montanensis, Paraorthacodus andersoni, Squalus worlandensis, and Archaeotriakis ornatus. This range extension follows a similar northern expansion of subtropical invertebrate biotas, "reaching central Canada" during the transgressive Bearpaw Cyclothem (Kauffman 1984, p. 297).

The euselachian assemblage reported by Beavan and Russell (1999) from the Lethbridge Coal Zone of the Dinosaur Park Formation underlies the Bearpaw Formation. As such, a faunal comparison between the two assemblages provides insight into changes in regional euselachian composition over a relatively short geological span of time. Of the ten species reported from the Dinosaur Park Formation, only three species (Meristodonoides montanensis, Odontaspis aculeatus, and Carcharias samhammeri) are present in the assemblage described herein. 
Noticeably absent from the Bearpaw assemblage are benthic euselachians. If we follow Musick et al. (2004, p. 38) and assume that "fossil forms had ecological attributes similar to closely related modern taxa", the recovered species from the assemblage were likely either pelagic or benthopelagic. Conversely, Beavan and Russell (1999) reported numerous benthic species from the Dinosaur Park Formation, including the orectolid Cretorectolobus olsoni and the batoids Ischyrhiza mira, Ptychotrygon blainense, Protoplatyrhina renae, and Myledaphus bipartitus. Teeth of the latter two species were by far the most frequently recovered fossil elements in the Lethbridge Coal Zone, thus the conspicuous lack of batoid specimens in the Bearpaw assemblage is likely palaeoecological in nature and not the result of sampling bias.

In their examination of ammonoid depth zonation, Tsujita and Westermann (1998, p. 157) reported that the "bottom-waters were of normal salinity and generally dysoxic" in the southern Alberta region of the WIS during the deposition of the Bearpaw Formation. This may have been the result of the Sweetgrass Arch (a submarine topographic high) that "inhibited the exchange of bottom-waters between the restricted Alberta Basin and the open seaway (to the southeast) during times of improved oxygenation in the seaway" (Tsujita and Westermann 1998, p. 153). The location of the euselachian assemblage described herein would have been situated west of this arch. Accordingly, the apparent absence of benthic euselachians corroborates the notion of adverse bottom waters in this region of the seaway during this time.

\section{Acknowledgements}


Collection of the studied euselachian specimens was made possible, thanks to the generous permission granted by the Hodgsons to gain access to their ranch. The authors extend their gratitude to Jerry Magraw (Penn State Behrend) for assistance with SEM imaging and to M. Templin for French translation of key references. TK also thanks D. Tanke, R. Russell, and M. Schilling (RTMP) for their field assistance that resulted in the discovery and recovery of the studied material. Comments by Jürgen Kriwet (University of Vienna), an anonymous reviewer, Anne de Vernal (Associate Editor), and Ali Polat (Editor) greatly improved the manuscript. This project was supported by Penn State Behrend 2015 Undergraduate Student Research Fellowship to EB and by Government of Alberta Japanese-Canadian Initiative Postdoctoral Fellowship to TK.

\section{References}

Agassiz, J.L.R. 1833-1844. Recherches sur les poissons fossils, 3. Imprimerie de Petitpierre, Neuchâtel.

Beavan, N.R. and Russell, A.P. 1999. An elasmobranch assemblage from the terrestrialmarine transitional Lethbridge Coal Zone (Dinosaur Park Formation: Upper Campanian), Alberta, Canada. Journal of Paleontology, 73: 494-503.

Becker, M.A., Chamberlain, J.A., and Terry, D.O. 2004. Chondrichthyans from the Fairpoint Member of the Fox Hills Formation (Maastrichtian), Meade County, South Dakota. Journal of Vertebrate Paleontology, 24: 780-793.

Becker, M.A., Chamberlain, J.A., and Wolf, G.E. 2006. Chondrichthyans from the Arkadelphia Formation (Upper Cretaceous: upper Maastrichtian) of Hot Spring County, Arkansas. Journal of Paleontology, 80: 700-716. 
Berg, L.S. 1958. System der Rezenten und Fossilen Fischartigen und Fische.

Hochschulbücher für Biologie, Berlin.

Bonaparte, C.L. 1834. Iconografia della fauna italic per le Quattro classi degli animali vertebrati. Tomo III. Pesci. Rome: Tip Salviucci.

Bonaparte, C.L. 1838. Selachorum tabula analytica. Nuovi Annali della Scienze Naturali, Bologna, 1: 195-214.

Buen, F. 1926. Catalogo ictiologico del Mediterraneo Español y de Marruecos, recopilando lo publicado sobrepeces de las costas mediterraneas y proximas del Atlantico (Mar de España). Resultados de las ampafias Realizadas por Acuerdos Internacionales. Instituto Español de Oceanografia, 2: 1-221.

Bullard, T.S. 2006. Anatomy and systematics of North American tylosaurine mosasaurs. Unpublished M.Sc. dissertation. University of Alberta, Edmonton, 208 pp.

Caldwell, W.G.E. 1968. The Late Cretaceous Bearpaw Formation in the South Saskatchewan River valley. Saskatchewan Research Council, Geology Division Report No. 8.

Caldwell, W.G.E., Diner, R., Eicher, D.L., Fowler, S.P., North, B.R., Stelck, C.R., von Holdt Wilhelm, L. 1993. Foraminiferal biostratigraphy of Cretaceous marine cyclothems. In Evolution of the Western Interior Basin. Geological Association of Canada, Edited by W.G.E. Caldwell and E.G. Kauffman. Special Paper 39, pp. $477-520$

Cappetta, H. 2012. Chondrichthyes. Mesozoic and Cenozoic Elasmobranchii: Teeth. In Handbook of Palaeoichthyology, Volume 3E. Edited by H.-P.Schultze. Verlag Dr. Friedrich Pfeil, München. 
Cappetta, H., and Case, G.R. 1975. Contribution à l'étude des Sélaciens du groupe Monmouth (Campanien-Maestrichtien) du New Jersey. Palaeontographica, Abt. A, 151: 1-46.

Case, G.R. 1978. A new selachian fauna from the Judith River Formation (Campanian) of Montana. Palaeontographica, Abt. A, 160: 176-205.

Case, G.R. 1987. A new selachian fauna from the Late Campanian of Wyoming (Teapot Sandstone Member, Mesaverde Formation, Big Horn Basin). Palaeontographica, Abt. A, 197: 1-37.

Case, G.R. 1996. A new selachian fauna from the Lower Hornestown Formation (Early Paleocene/Montian) of Monmouth County, New Jersey. Palaeontographica, Abt. A, 242: 1-14.

Case, G.R., and Cappetta, H. 1997. A new selachian fauna from the Late Maastrichtian of Texas (Upper Cretaceous/Navarroan; Kemp Formation). Müenchner Geowissenschaftliche Abhandlungen Reihe A Geologie und Paläeontologie 34: $131-189$.

Casier, E. 1967. Le Landénien de Dormaal (Brabant) et sa faune ichthyologique. Mémoires de l'Institut Royal des Sciences Naturelles de Belgique, 156: 1-66. Compagno, L.J.V. 1973. Interrelationships of living elasmobranchs. In Interrelationships of Fishes. Edited by P.H. Greenwood, R.S. Miles, and C. Patterson. Zoological Journal of the Linnean Society 53, pp. 15-61.

Compagno, L.J.V., and Follett, W.I. 1986. Carcharias Rafinesque, 1810 
(Chondrichthyes, Lamniforms): proposed conservation by the use of the relative precedence procedure. Z. N. (S) 2414. Bulletin of Zoological Nomenclature, 43: 89-92.

Cvancara, A.M., and J.W. Hoganson. 1993. Vertebrates of the Cannonball Formation (Paleocene) in North and South Dakota. Journal of Vertebrate Paleontology, 13: $1-23$.

Daimeries, A. 1888. Notes ichthyologiques (Système Landénien) - I. Annales de la Société royale malacologique de Belgique, Bulletin des des Séances 23: 42-43.

Glikman, L.S. 1957. On the relationships between the families Lamnidae and Odontaspidae and on new lamnid genera from the Late Cretaceous. Trudy Geologischeskogo Muzeja “A. P. Karpinskogo,” Akademia Nauk SSSR, 1: 110117. [In Russian].

Glikman, L.S. 1958. Rates of evolution in Lamnoid sharks. Doklady Akademij Nauk SSSR, 123: 568-571. [In Russian].

Goodrich, 1909. Vertebrata Craniata. I. Cyclostomes and fishes. A Treatise on Zoology, Part 9. London: Adam and Charles Black.

Gray, J.E. 1851. List of the Specimens of Fish in the Collection of the British Museum. Part I. Chondropterygii. British Museum (Natural History), London.

Gurr, P.R. 1962. A new fish fauna from the Woolwich Bottom Beds (Sparnacian) of Herne Bay, Kent. Proceedings of the Geologists' Association, 73: 419-447. Hartstein, E., Decina, L., and Keil, R. 1999. A late Cretaceous (Severn Formation) Vertebrate Assemblage from Bowie Maryland. Mosasaur, 6: 17-24. 
Hay, O.P. 1902. Bibliography and catalogue of the fossil Vertebrata in North America. United States Geological Survey Bulletin, 179: 1-868.

Herman, J. 1973. Contribution à la connaissance de la faune ichthyologique des phosphates du Maroc. Annales de la société géologique de Belgique, 95: 271284.

Holmes, R. 1996. Plioplatecarpus primaevus (Mosasauridae) from the Bearpaw Formation (Campanian, Upper Cretaceous) of the North American Western Interior Seaway. Journal of Vertebrate Paleontology, 16: 673-687.

Holmes, R., Caldwell, M.W., and Cumbaa, S.L. 1999. A new specimen of Plioplatecarpus (Mosasauridae) from the lower Maastrichtian of Alberta: comments on allometry, functional morphology, and paleoecology. Canadian Journal of Earth Sciences, 36: 1-7.

Huxley, T.H. 1880. On the application of the laws of evolution to the arrangement of the Vertebrata and more particularly of the Mammalia. Proceedings of the Zoological Society of London, 1880: 649-662.

Kent, B.W. 1994. Fossil Sharks of the Chesapeake Bay Region. Columbia, MD. Egan Rees and Boyer, Inc.

Konishi, T., Brinkman, D., Massare, J.A., and Caldwell, M.W. 2011. New exceptional specimens of Prognathodon overtoni (Squamata, Mosasauridae) from the upper Campanian of Alberta, Canada, and the systematics and ecology of the genus. Journal of Vertebrate Paleontology, 31: 754-783.

Konishi, T. 2012. The northernmost occurrence of Prognathodon (Squamata: 
Mosasauridae) from the Western Interior Seaway of North America. Canadian Journal of Earth Sciences, 49: 1-5.

Konishi, T., Newbrey, M.G., and Caldwell, M.W. 2014. A small, exquisitely preserved specimen of Mosasaurus missouriensis (Squamata, Mosasauridae) from the upper Campanian of the Bearpaw Formation, wetsern Canada, and the first stomach contents for the genus. Journal of Vertebrate Paleontology, 34: 802-819.

Kubo, T., Mitchell, M.T., and Henderson, D.M. 2012. Albertonectes vanderveldei, a new elasmosaur (Reptilia, Sauropterygia) from the Upper Cretaceous of Alberta. Journal of Vertebrate Paleontology, 32: 557-572.

Kauffman, E.G. 1984. Paleobiogeography and evolutionary response dynamic in the Cretaceous Western Interior Seaway of North America. In Jurassic-Cretaceous Biochronology and Biogeography of North America. Edited by G.E.G. Westerman. Geological Association of Canada, Special paper 27, pp. 273-306.

Lerbekmo, J.F. 2002. The Dorothy bentonite: an extraordinary case of secondary thickening in a late Campanian volcanic ash fall in central Alberta. Canadian Journal of Earth Sciences, 39: 1745-1754.

Linnaeus, C. 1758. Systema Naturae per regna tria naturae, regnum animale, secundum classes, ordines, genera, species, cum characteribus differentiis synonymis, locis. Ed. X., Stockholm.

Mahaney, W.C., Barendregt, R.W., Allen, C.C.R., Milner, M.W., and Bray, D. 2013. Coprolites from the Cretaceous Bearpaw Formation of Saskatchewan. Cretaceous Research, 41: 31-38.

Maisey, J.G. 1975. The interrelationships of phalacanthous selachians. Neues Jahrbuch 
für Geologie und Paläontologie, Monatshefte, 1975: 553-567.

Müller, J., and Henle, F.G.J. 1838-1841. Systematische Beschreibung der Plagiostomen. Berlin.

Musick, J.A., Harbin, M.M., and Compagno, L.J.V. 2004. Historical zoogeography of the Selachii. In Biology of Sharks and Their Relatives. Edited by J.C. Carrier, J.A. Musick, and M.R. Heithaus. CRC Press, Boca Raton, pp. 33-78.

Owen, R. 1846. Lectures on the Comparative Anatomy and Physiology of the Vertebrate Animals. Part 1. Fishes. London: Longman, Brown, Green, and Longmans.

Rafinesque, C.S. 1810. Caratteri di alcuni nuovi generi e nuove specie di animali e piante della Sicilia, con varie osservazioni sopra I medisimi. Palermo (Sanfilippo).

Sato, T. 2003. Terminonatator ponteixensis, a new elasmosaur (Reptilia; Sauropterygia) from the Upper Cretaceous of Saskatchewan. Journal of Vertebrate Paleontology, 23: $89-103$.

Sato, T. 2005. A new polycotylid plesiosuar (Reptilia: Sauropterygia) from the Upper Cretaceous Bearpaw Formation in Saskatchewan, Canada. Journal of Paleontology, 79: 969-980.

Siverson, M. 1992a. Late Cretaceous Paraorthacodus (Palaeospinacidae, Neoselachii) from Sweden. Journal of Paleontology, 66: 994-1001.

Siverson, M. 1992b. Biology, Dental Morphology and Taxonomy of Lamniform Sharks from the Campanian of the Kristianstad Basin, Sweden. Palaeontology, 35: 519554.

Siverson, M., and Lindgren, J. 2005. Late Cretaceous sharks Cretoxyrhina and Cardabiodon from Montana, USA. Acta Palaeontologica Polonica, 50: 301-334. 
Tokaryk, T. 1993. A plioplatecarpine mosasaur from the Bearpaw shale (Upper Cretaceous) of Saskatchewan, Canada. Modern Geology, 18: 503-508.

Tsujita, C.J., and Westermann, G.E.G. 1998. Ammonoid habitats and habits in the Western Interior Seaway: a case study from the Upper Cretaceous Bearpaw Formation of southern Alberta, Canada. Palaeogeography, Palaeoclimatology, Palaeoecology, 144: 135-160.

Underwood, C.J., and Cumbaa, S.L. 2010. Chondrichthyans from a Cenomanian (Late Cretaceous) bonebed, Saskatchewan, Canada. Palaeontology, 53: 903-944.

Ward, D.J., and Wiest, R.L. 1990. A checklist of Palaeocene and Eocene sharks and rays (Chondrichthyes) from the Pamunkey Group, Maryland and Virginia, USA. Tertiary Research, 12: 81-88.

\section{Figure captions}

Figure 1. Specimen locality and horizon. A, map of southern Alberta showing the Bearpaw Formation exposures in grey. Black star indicates the locality along the Red Deer River near Dorothy, east of Drumheller. Inset map represents the late Campanian North America, showing the new locality (solid arrow) within the embayment along the western margin of the Western Interior Seaway. B, stratigraphic column along with a locality photo, indicating approximate horizon the euselachian material was collected from. Dry, bulk sampling was done near the top of the 10-m-thick Dorothy Bentonite. Abbreviations used in figures: D.B., Dorothy bentonite; D.P., Dinosaur Park Formation; D.S., Dorothy sandstone; H.C., Horseshoe Canyon Formation. Geological map and 
locality photo modified from Konishi (2012:fig. 1), late Campanian paleogeography from Tsujita and Westermann (1998), and stratigraphic column modified from Lerbekmo (2002:fig. 2). A person for scale in the locality photo.

Figure 2. Hybodontiform, hexanchiform, and squaliform teeth recovered from the late Campanian Bearpaw Formation of southern Alberta. A. Meristodonoides montanensis (Case, 1978), TMP 2011.048.0232 (incomplete tooth); B. M. montanensis, TMP 2011.048.0325 (incomplete tooth); C. Paraorthacodus andersoni (Case, 1978), TMP 2011.048.0097 (incomplete lateral tooth); D. Squalus worlandensis (Case, 1987), TMP 2011.048.0196 (nearly complete lateral tooth); E. S. worlandensis, TMP 2011.048.0323 (complete lateral tooth); F. S. worlandensis, TMP 2011.048.0269 (incomplete lateral tooth); G. S. worlandensis, TMP 2011.048.0324 (incomplete lateral tooth). Views: labial (left) and lingual (right) for A, B, C, E, and G; labial (top) and lingual (bottom) for D and F. Scale bars $=1 \mathrm{~mm}$.

Figure 3. Lamniform and carcharhiniform teeth recovered from the late Campanian Bearpaw Formation of southern Alberta. A. Carcharias cf. C. samhammeri (Cappetta and Case, 1975), TMP 2011.048.0291 (incomplete lower anterior tooth); B. Carcharias cf. C. samhammeri, TMP 2011.048.0156 (incomplete upper anterior tooth); C. Carcharias cf. C. samhammeri, TMP 2011.048.0187 (incomplete upper lateral tooth); D. Carcharias cf. C. samhammeri, TMP 2011.048.0228 (incomplete posterior tooth); E. Odontaspis aculeatus (Cappetta and Case, 1975), TMP 2011.048.0221 (incomplete anterior tooth); F. O. aculeatus, TMP 2011.048.0215 (incomplete lower lateral tooth); G. O. aculeatus, 
TMP 2011.048.0222 (incomplete upper lateral tooth); H. O. aculeatus, TMP 2011.048.0217 (incomplete upper lateral tooth); I. Cretoxyrhina mantelli (Agassiz, 1843), TMP 2011.048.0274 (incomplete lateral tooth); J. Archaeotriakis ornatus (Case, 1987), TMP 2011.048.0237 (incomplete tooth). Views: labial (left) and lingual (right) for A, B, D, E, F, G, and H; labial (left), profile (center), lingual (right) for I; labial (top) and lingual (bottom) for D and J. Scale bars $=1 \mathrm{~mm}$. 


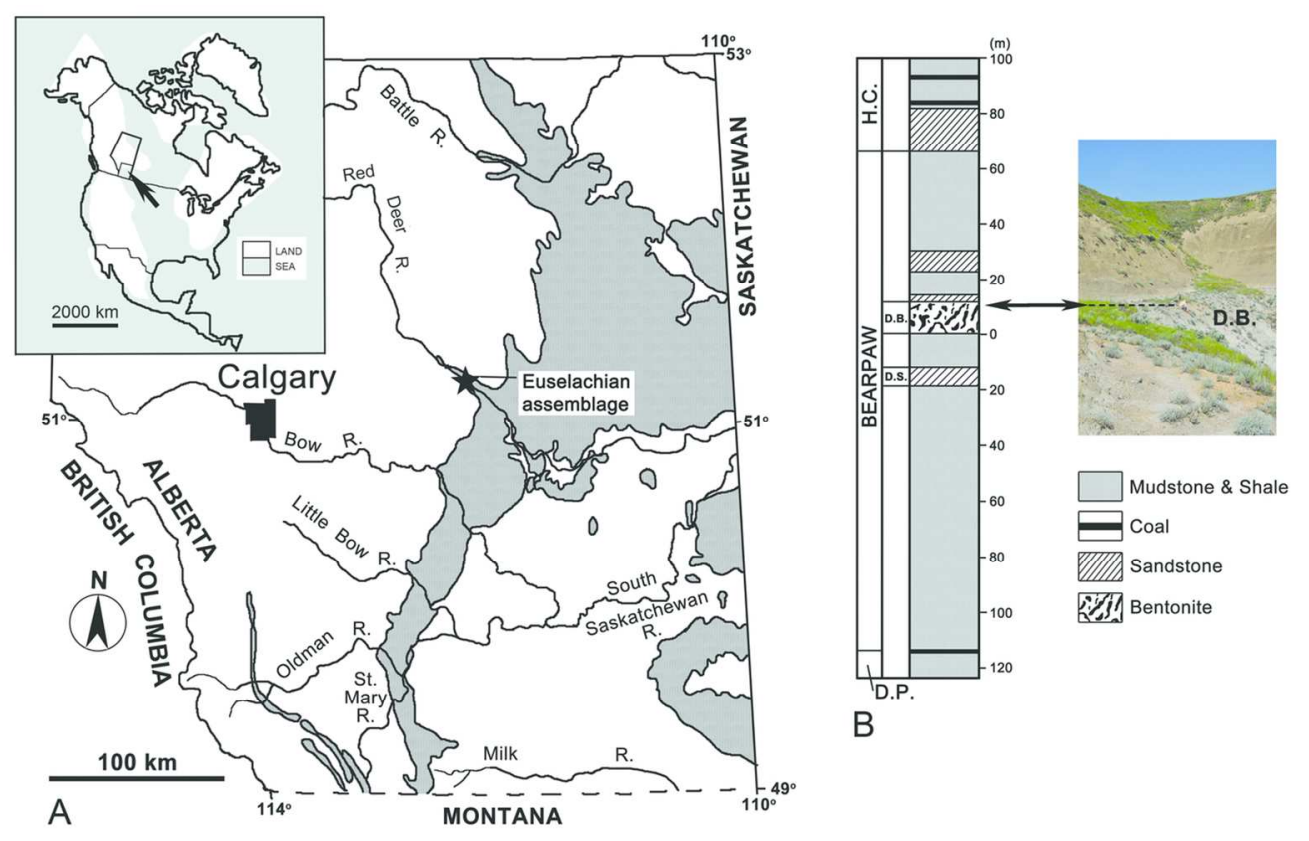

Figure 1

$117 \times 75 \mathrm{~mm}(300 \times 300 \mathrm{DPI})$ 


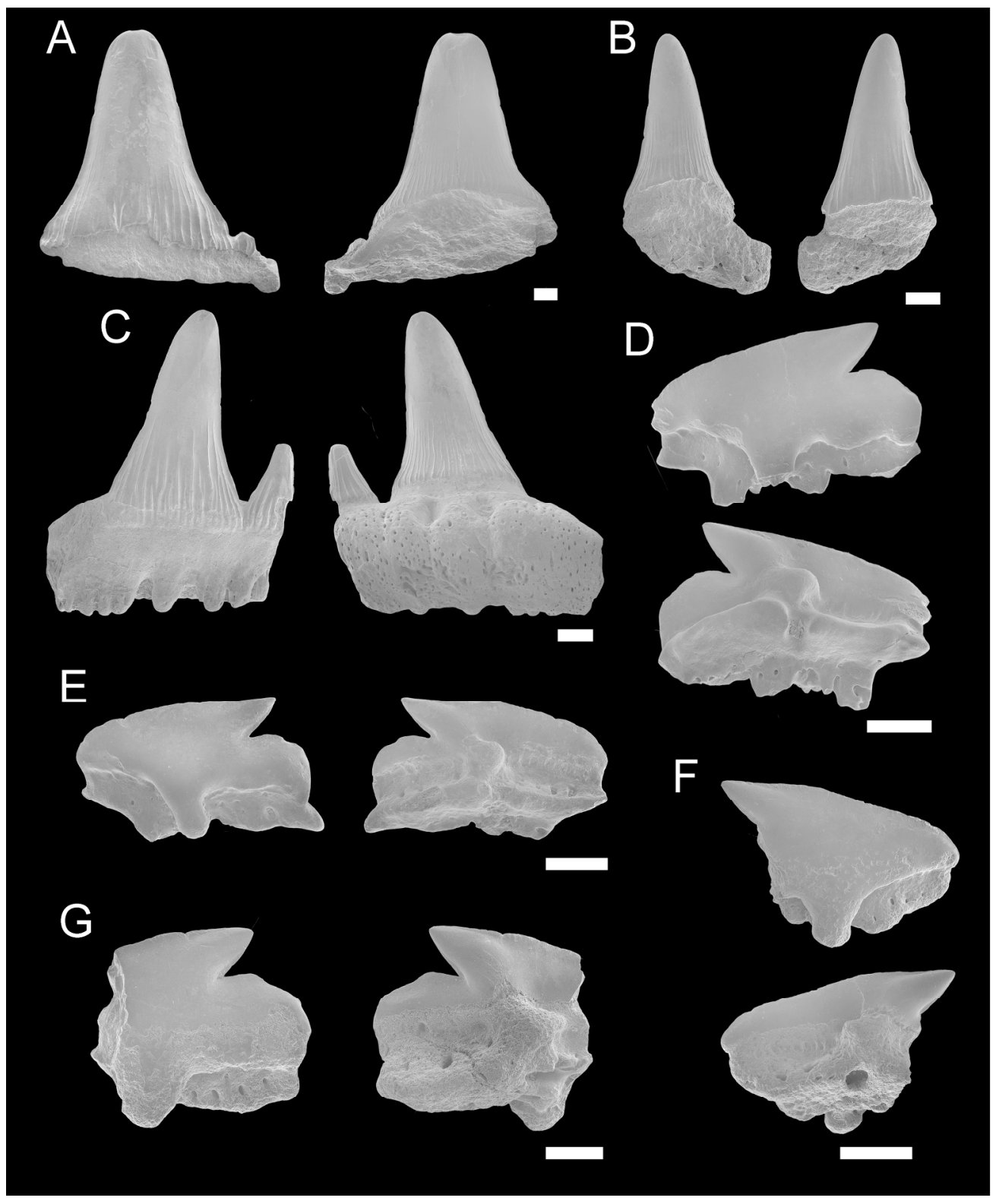

Figure 2

$220 \times 266 \mathrm{~mm}(300 \times 300 \mathrm{DPI})$ 


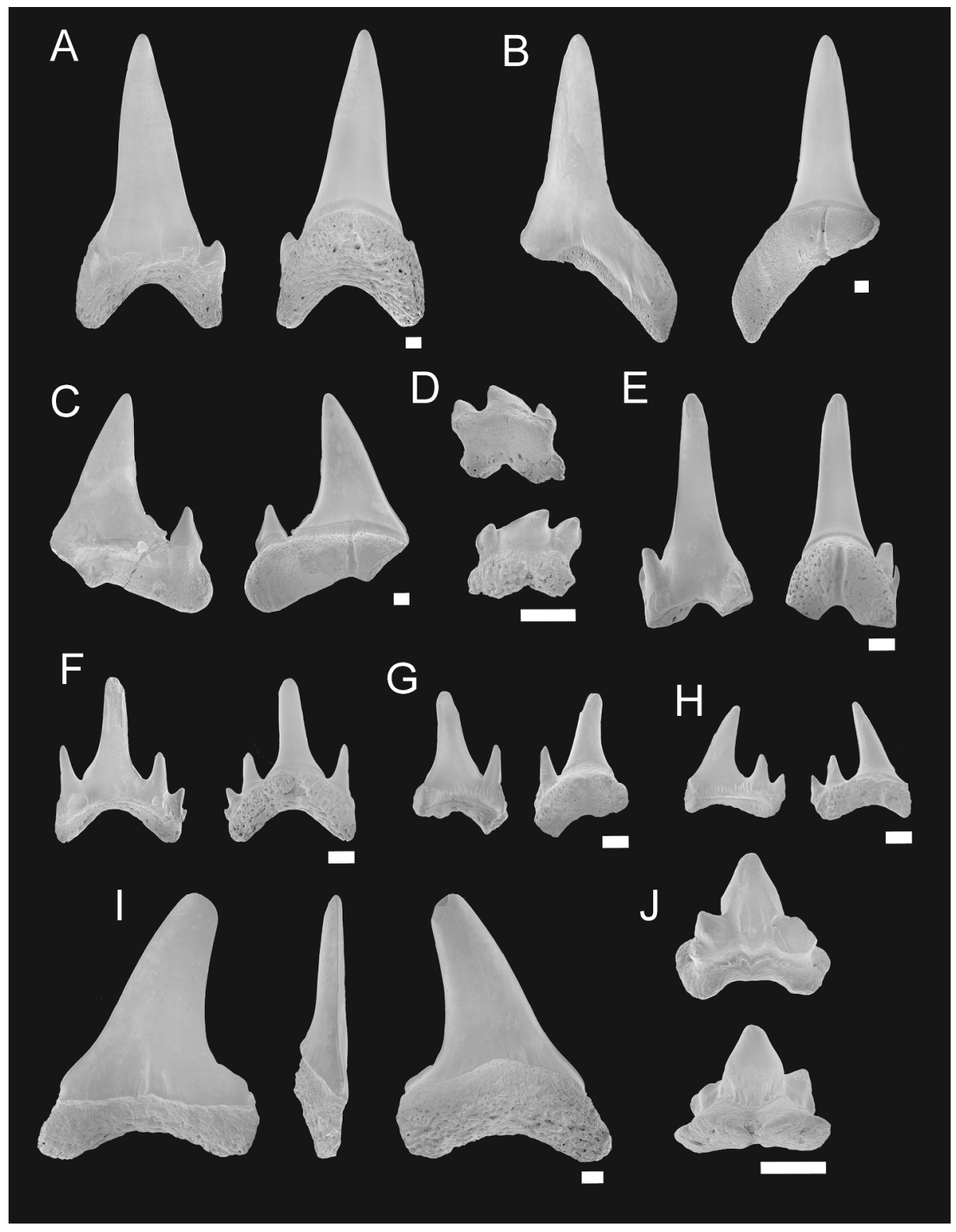

Figure 3

$236 \times 305 \mathrm{~mm}(300 \times 300 \mathrm{DPI})$ 


\section{Supplementary Data}

Number of specimens recovered from microsites and surface collection of the Bearpaw Formation in Dorothy, Alberta, Canada

\begin{tabular}{|c|c|c|c|c|c|c|}
\hline Taxa & DSnail & $\begin{array}{c}\text { MSnail- } \\
1\end{array}$ & $\begin{array}{c}\text { MSnail- } \\
2\end{array}$ & $\begin{array}{c}\text { MSnail- } \\
3\end{array}$ & TSnail & $\begin{array}{l}\text { Surface } \\
\text { Collected }\end{array}$ \\
\hline $\begin{array}{l}\text { Meristodonoides } \\
\text { montanensis }\end{array}$ & 1 & 2 & - & - & - & - \\
\hline $\begin{array}{l}\text { Paraorthacodus } \\
\text { andersoni }\end{array}$ & 1 & - & - & - & 1 & - \\
\hline Squalus worlandensis & - & 4 & & - & 2 & - \\
\hline $\begin{array}{l}\text { Carcharias cf. } C \text {. } \\
\text { samhammeri }\end{array}$ & 4 & 3 & - & 1 & 1 & 3 \\
\hline Odontaspis aculeatus & 1 & 7 & - & - & 1 & - \\
\hline Cretoxyrhina mantelli & - & - & - & - & - & 1 \\
\hline Archaeotriakis ornatus & - & 1 & - & - & - & - \\
\hline $\begin{array}{l}\text { Lamniform indet. } \\
\text { (highly incomplete) }\end{array}$ & 40 & 58 & 5 & 2 & 10 & 21 \\
\hline
\end{tabular}

